\title{
ACCESS TO JUSTICE AS ILLUSTRATED BY THE INSTITUTE OF SMALL CLAIMS: AN ASSESSMENT OF THE PROCEDURAL LAW REFORM IN UKRAINE
}

\author{
Nazar Panych, \\ Dr. jur., LL.M., Professor and researcher \\ of the Institute of East European Law, \\ University of Kiel \\ (Kiel, Federal Republic of Germany)
}

https://doi.org/10.33327/AJEE-18-2.1-a000009

Summary: 1. Introduction. - 2. Sources of Law of Small Claims. - 3. The Purpose and Principles of the Institute of Small Claims. - 4. Value of a Claim. - 5. Change of the Value of a Claim. - 6. Consideration of Small Claims. - 7. Representation of the Parties during Small Case Consideration. - 8. Evidence and Prooving when Considering Small Claims. - 9. Appeal against Court Decisions in Small Claims. - 10. Cassation Appeal against Court Decisions in Small Claims. - 11. Conclusions

On 15-16 October 1999, a meeting of the European Council, whose influence on the development of civil process in the EU cannot be overestimated, took place in Tampere. It was at this meeting that the need was declared to develop and implement the EU level rules of procedure, which should simplify and accelerate cross-border litigation (within the EU). As a result, the Regulation (EC) No 861/2007 of the European Parliament and the Council of 11 July 2007 establishing a European small claims procedure was adopted. ${ }^{1}$ On the basis of this Regulation, the European legislators sought to introduce a small claims procedure directly in the EU. However, their intentions and efforts have also become the guideline for legislators of those states that (so far) are not members of the EU, in particular, Ukraine. In more than a decade, the institute of small claims has found its consolidation in the reformed civil process of Ukraine, an associate partner of the EU. In this context, the question arises: have the goals and results of the institutes' implementation coincided within the law of the EU and Ukraine? Is there a positive experience of such an

1 Regulation (EC) No 861/2007 of the European Parliament and the Council 11 July $2007<$ https:// eur-lex.europa.eu/legal-content/EN/TXT/HTML/?uri=CELEX: 32007R0861\&from=de $>$ accesed 15 February 2019. 
introduction and does this institute need further reforms? This publication is an attempt to provide answers to these questions.

Key words: small claims, regulations, law, justice, court, claim, proof, simplicity, speed, proportionality of the trial

\section{INTRODUCTION}

The consolidation of the rule of law is characteristic of constitutions of many European countries. ${ }^{2}$ To answer the question whether such a constitutional provision is (more) of a declarative nature or is really implemented in practice, one should take a look at other national legislator's initiatives. After all, it is their analysis that will allow us to assess the effectiveness of the intentions to reform the national law in order to secure the rule of law. For the purpose of achieving this goal in the Ukrainian context, promising is the analysis of access to justice illustrated by the institute of small claims. ${ }^{3}$ This institute was introduced by the national legislator in Ukrainian procedural law in the framework of the 2017 reform.

The Law of Ukraine 'On Amendments to the Commercial Procedure Code, Civil Procedure Code, Code of Administrative Procedure and Other Legislative Acts' entered into force on 15 December 2017. This law marked the consolidation of a number of novels in the Ukrainian legislation, including in civil procedural law. ${ }^{4}$ The novels were intended to reform this branch of Ukrainian law by bringing it in line with the European standards. In this regard, the question arises whether this goal was achieved and whether the novels correspond to the EU law and the law of particular EU members, such as the Federal Republic of Germany (hereinafter referred to as Germany). The volume of this work does not allow analysing all the novels of the Civil Procedure Code, and therefore the emphasis in this work will be put on the general analysis of one of them - the institute of small claims

\section{SOURCES OF LAW OF SMALL CLAIMS}

At the pan-European level, the central source of law for small claims is the Regulation (EC) No 861/2007 of the European Parliament and of the Council of 11 July 2007 establishing a European small claims procedure. Like other EU legal acts, the Regulation (EC) No 861/2007 has a clear structure: it consists of four

2 For example, Article 1 of the Constitution of Ukraine of 28 June 1996 (with amendments); comparable rules are stipulated in Article 28 of the Fundamental Law of the Federal Republic of Germany of 23 May 1949 (with amendments) and in the Constitution of the Kingdom of Spain of 29 December 1978 (with amendments).

3 This text is a supplemented and revised edition of the publication of NY Panych, 'Small Claims According to Part 6 Article 19 of the CPC of Ukraine in Comparison with Para 495a of the CPC of Germany and Part 1 Article 2 of the Regulation (EC) No 861/2007: Is the reform a Success?' in I Izarova, R Fleishar, R Hanyk-Pospolitak (eds), Small Claims: European and Ukrainian Experience of Consideration (Materials of International Scientific and Practical Conference, Dakor 2018) 120-133.

4 O Kovalyshyn, 'Novellierung der ukrainischen Zivilprozessordnung' (2018) 3 WIRO 72. 
chapters comprising a total of 29 articles. In addition, the Regulation includes four annexes with forms aimed at standardizing written (as a rule) proceedings in small claims. ${ }^{5}$ Such annexes are, in particular, claim form (A), request by the court or tribunal to complete and/or rectify the claim form (B), answer form (C) and certificate concerning a judgment in the European small claims procedure (D). According to the summary decision, the Regulation (EC) No 861/2007 shall be binding in its entirety. ${ }^{6}$ In accordance with the Treaty of Rome of 25 March 1957 in the wording of 30 November 2009, its provisions shall be directly applicable in all the Member States with the exception of Denmark. ${ }^{7}$

In the German law, the rules governing the institute of small claims are concentrated in the Civil Procedure Code of Germany (Zivilprozessordnung) (hereinafter referred to as the CPC of Germany) ${ }^{8}$ in the wording of 5 December 2005. The CPC of Germany contains two blocks of rules that govern the institute of small claims. First of all, it is Para 495a of the CPC of Germany, which regulates small claims proceedings (Bagatellverfahren). Despite the extraordinary generality of the wording in this paragraph and the absence of clear contours ${ }^{9}$ in them, its practical relevance remains indisputable. ${ }^{10}$

In addition, a separate set of norms of the CPC of Germany is enshrined in Chapter 6 of the eleventh book of the CPC. The subject of the regulation of this chapter is 'The European Small Claims Proceedings in Accordance with Regulation (EC) No 861/2007. Thus, in Germany, a person who seeks to go to court following the procedure provided for by law for small claims has two options for such an appeal. First of all, when applying to a national court, he/she can apply for a proceeding on the basis of national law (Para 495a of the CPC of Germany). In addition, in the event of a cross-border dispute within the EU following the statutory prerequisites, such person may also take advantage of applying for proceedings under the Regulation (EC) No 861/2007. ${ }^{11}$

In the Ukrainian law, the institute of small claims is regulated by the Civil Procedural Code of Ukraine of 18 March 2004, with corresponding amendments (hereinafter referred to as the CPC of Ukraine). ${ }^{12}$ The rules of this Code concerning the institute of small claims are not concentrated in a single subdivision. On the contrary, they are constituent parts of several units of the CPC of Ukraine, for example, Para 1 of the second chapter of the first section of the CPC of Ukraine 'Subject Matter

5 J Adolphsen, Europäisches Zivilverfahrensrecht (2 Aufl, Springer Verlag 2015) para 10 Rn 2.

6 For critique of this rules, see W Hau in MüKoZPO: EG-BagatellVO (5 Aufl, CH Beck 2016) Art 29 Rn 1.

7 A Brokamp, Das Europäische Verfahren für geringfügige Forderungen (Mohr Siebeck 2008) 3.

8 Bundesamt für Justiz: Zivilprozessordnung <www.gesetze-im-internet.de/zpo/> accessed 16 February 2019.

9 See critique Kammergericht Berlin, Beschluss vom 15.06.2001 - 20010615 Aktenzeichen 28 W $22 / 01$.

10 See section 3 of this article for the number of small claims considered by the courts of Germany.

11 G Deppenkemper in MüKoZPO (5 Aufl, CH Beck 2016) para 495a Rn 3.

12 Civil Procedure Code of Ukraine <https://zakon.rada.gov.ua/laws/show/1618-15> accessed 16 February 2019. 
and Personal Jurisdiction' and the tenth chapter of the third section of the CPC 'Consideration of Cases under Simplified Procedure.' Thus, the Ukrainian legislator abandoned the concept of accumulation of lex specialis concerning small claims in one particular subdivision, preferring to include these norms in various thematically formed parts of the CPC of Ukraine.

\section{THE PURPOSE AND PRINCIPLES OF THE INSTITUTE OF SMALL CLAIMS}

Before analysing the regulation of the institute of small claims, it is worth to mention the reasons that have led to its introduction at the EU level. One of these reasons was the desire to create a single integrated consumer protection system in the EU, by regulating, in particular, the procedural aspects of such protection. ${ }^{13}$ Thus, the purpose of consumer rights protection was, and still remains, one of the leitmotifs of the legislator when adopting the Regulation (EC) No 861/2007. It is manifested in many of its provisions and is one of the main incentives for the modernization of the EU legislation, including the abovementioned Regulation. ${ }^{14}$

Many Member States have already provided for appropriate regulation in the national law, but there was no all-European harmonized system of rules. To this end, aiming at facilitating access to justice for the EU citizens, the efforts of the European legislator were directed towards the development of a unified legal framework for the institute of small claims. The basic principles of this institute have become the simplicity, speed and proportionality of consideration of small claims. ${ }^{15}$ Having facilitation of access to justice in mind as the purpose of small claims, it is the abovementioned three principles that should be central criteria for assessing the effectiveness of the relevant national rules.

Consideration of the institute of small claims should be focused on two aspects. First of all, of high interest are the preconditions for qualifying claims as small. In addition, a comparative analysis of the peculiarities of small claims consideration in Ukraine and Germany is relevant.

\section{VALUE OF A CLAIM}

Both at the EU level and in the national law of Germany the criterion of the value of a claim is foreseen as a precondition for qualifying the claim to the category of small ones. The EU law provides for a fairly high threshold for eligible small claims. According to Part 1, Article 2 of the Regulation (EC) No 861/2007, the category of small claims comprises ones with the value not exceeding 5,000 Euro. ${ }^{16}$ It should

13 B Hess, Europäisches Zivilprozessrecht (Müller 2010) para 10 Rn 87.

14 See, for example, section 3 of this article for change of the threshold of small claims value with the aim of expanding the list of subjects covered by the rules oft he Regulation (EC) No 861/2007.

15 Item 7 of the Proposals to the Regulations (EC) No 861/2007.

16 See item 5 of the Proposals to the Regulations (EC) No 861/2007. 
be mentioned that, until 14 July 2017, the Regulation (EC) No 861/2007 in the old wording provided for a limit of the value of a claim which was more than twice lower. According to Part 1, Article 2 of the Regulation (EC) No 861/2007 in the old wording, the matters where the value of a claim did not exceed 2,000 Euro were considered as small claims. However, the Regulation (EC) No 2015/2421 of 16 December $2015^{17}$, which entered into force on 14 July 2017, provided for an increase of the threshold for eligible small claims up to 5,000 Euro in Part 1, Article 1. The reason for this increase was the desire of the European legislator to improve the access of parties (consumers and small and medium-sized enterprises above all) to effective and affordable legal protection (Para 5 of the Proposals for a Regulation). ${ }^{18}$

The procedural law of Germany is also familiar with the criterion of the value of a claim. Unlike the Regulation, Para 495a of the CPC of Germany at the national level provides for a substantially lower threshold for eligible small claims. In particular, a matter is considered as a small claim, if the value of a claim does not exceed 600 Euro. Interest and other costs declared as an additional requirement are not subject to consideration when determining the value of a claim. ${ }^{19}$ Data from the Federal Statistical Office of Germany show the practical relevance of the legal regulation of the institute of small claims. According to the latest published data of this office as of 1 January 2019, of the total number of completed procedures (952,413 procedures), approximately $7.69 \%$ belonged to small claims procedures $\left(73,298\right.$ procedures). ${ }^{20}$

The criterion of the value of a claim is also present in the Ukrainian law. According to Part 6 of Article 19 of the CPC of Ukraine, the cases in which the value of a claim does not exceed one hundred sizes of the subsistence minimum for able-bodied persons are considered as small claims. In addition, matters of low complexity recognized by the court as small claims may also be classified as small claims, except cases that are to be considered only under general procedure, and those cases where the value of a claim exceeds five hundred subsistence minimum sizes for able-bodied persons. Thus, one of the criteria for crediting a case to a category of small claims in procedural law of Ukraine is the value of a claim. In addition, independently from the previous criterion, the matter may be qualified as a small claim by Ukrainian court. Taking into account the size of the subsistence minimum for able-bodied persons as of 1 February $2019^{21}$ in the amount of 1,921 UAH, and in the sense of Part 6 of Article 19 of the CPC

17 Regulation (EC) No 2015/2421, 16 December 2015 <https://eur-lex.europa.eu/legal-content/DE/ TXT/?uri=CELEX\%3A 32015R2421> accessed 15 February 2019.

18 In the process of reforming the institute of small claims, the European Committee has even prepared a proposal for the additional increase of the threshold of the value of small claims up to 10,000 Euro. Agrumentation for such a step were, among others, the results of the survey, according to which $66 \%$ of the respondents said that an increase of the threshold of the value of small claims was one of the ways of facilitating access to justice, see COM (2013) 794, Clause 2. G Toussaint in V Vorwerk, C Wolf (eds), BeckOK ZPO (30 ed 15.9.2018), para 495a Rn 2.

20 Statistisches Bundesamt, Rechtspflege, Zivilgerichte (Fachserie 10, Reihe 2.1, Destatis 2017) 38.

21 For the size of the subsistence minimum for able-bodied persons according to Art 7 of the Law of Ukraine 'On the State Budget of Ukraine for 2019', see <https://zakon.rada.gov.ua/laws/show/ 2629-19> accessed 16 February 2019. 
of Ukraine, a small claim is the matter, in which the value of the claim does not exceed 192,100 UAH. Considering the official NBU rate as of 7 February $2019^{22}$ in the equivalent of 1 Euro / $30.58 \mathrm{UAH}$, a small claim, in the sense of Part 6 of Article 19 of the CPC of Ukraine, is a case in which the value of the claim does not exceed approximately 6,281 Euro.

\section{CHANGE OF THE VALUE OF A CLAIM}

Under certain conditions, one of the parties of the proceeding may apply to the court for an increase in the amount of claims or for changing the subject of the claim. If such procedural action leads to an increase in the value of a claim, then it should also lead to a new legal assessment of the conformity of such a case with the criteria of small claims.

The Regulation (EC) No 861/2007 does not contain a direct rule that would regulate the legal consequences of exceeding the value of a claim beyond the amount set forth in Part 1 of Article 2 of the Regulation. Such a rule was set by the European legislator only for cases of exceeding the value of a counterclaim in part 7 of Article 5 of the Regulation. ${ }^{23}$ At the same time, the literature rightly notes that in case of exceeding the value of a claim, the legal consequences, stipulated by Part 3 of Article 4 of the Regulation, are subject to application. According to this rule, the procedure is re-qualified from the category of small claims procedure to the general procedure with its subsequent consideration under the rules of lex fori. ${ }^{24}$

Comparable legal consequences in the event of a change in the value of a claim were also foreseen by the CPC of Germany. In case of exceeding the value of the claim stipulated by Para 495a of the CPC of Germany due to a change in claim or an increase in the amount of claims, such a dispute is subject to review under the rules of general proceedings. ${ }^{25}$

The Ukrainian legislator also resolved the issue of changing the value of a claim and its impact on the legal assessment of the qualifications of the matter as a small claim. Appropriate legal consequences were stipulated in Part 5 of Article 274 of the $\mathrm{CPC}$ of Ukraine. According to this provision, the court refuses to consider a matter under simplified procedure or decides to hear a case under general procedure, if the relevant small claim cannot be considered in simplified proceedings after a court's admission of the claimant's application for increasing the value of a claim or changing the subject of a claim.

22 See official currency exchange rate of the NBU <https://bank.gov.ua/control/uk/curmetal/detail/ currency?period=daily $>$ accessed 16 February 2019.

23 J Kropholler, J von Hein, Europäisches Zivilprozessrecht: EuGFVO (9 Auflage, Deutscher Fachverlag $\mathrm{GmbH}$ ) Art 3 Rn 14.

24 I Varga in T Rauscher (ed), Europäisches Zivilprozess- und Kollisionsrecht EuZPR/EuIPR (Bd II, 4 neu bearbeitete Auflage, EG-BagatellVO, Otto Schmidt 2015) Art 2 Rn 10.

25 HJ Musielak,W Voit, J Wittschier, ZPO (15 Aufl, Vahlen 2018) para 495a Rn 4. 


\section{CONSIDERATION OF SMALL CLAIMS}

The Regulation (EC) No. 861/2007 as well as German and Ukrainian procedural law regulate the procedure for small cases consideration under simplified procedure.

The central provision of the Regulation (EC) No 861/2007 which defines the procedure for small cases consideration is Article 5 of the Regulation. Part 1 of this article stipulates that the small claims procedure shall be a written procedure. ${ }^{26}$ Exceptions to this rule are possible in the presence of conditions established in Part 1 of Article 5 of the Regulation. In particular, according to the first sentence of this part, a court may hold an oral hearing if it considers that it is impossible to make a decision on a case only on the basic written evidence. In addition, the court may hold an oral hearing if one of the parties so requests. Both rules are formulated as 'rules of authority', that is, the court may, but is not obliged to hold an oral hearing. It is confirmed by the second sentence of Part 1a of Article 5 of the Regulation. According to it, the court may refuse a party's request for an oral hearing if it considers that with regard to the circumstances of the case, an oral hearing is obviously not necessary for the fair conduct of the proceedings. In this case, the court is obliged to substantiate in writing the refusal of such a request of the party. Separate appeals against such a refusal without appeal of the decision itself are not allowed. And although there are separate voices in the literature in support of the abovementioned broad powers of the court to consider cases 'at its own discretion,' most scholars are united in the rigorous critique of such a dubious European legislator's approach to this aspect. ${ }^{27}$

The German legislator has refused to give a judge broad powers to consider small cases at their own discretion. According to the clear wording of Para 495a of the CPC, in the presence of a respective request of one of the parties, consideration of the case by the court should be carried out orally, that is, with the notification (summons) of the parties. ${ }^{28}$ The German doctrine emphasizes the importance of this postulate, which seeks to guarantee the right to a fair and public trial under Article 6 Para 1 of the Convention for the Protection of Human Rights and Fundamental Freedoms. ${ }^{29}$ The need to comply with this right had already been enshrined in Para 495 of the CPC at the stage of its development and inclusion in the CPC of Germany. ${ }^{30}$ Its immutability has been repeatedly confirmed and is still being confirmed by German judicial practice, including the decision of the Federal Constitutional Court. Although some scholars admit that the German court has the right to refuse an oral hearing of a case if the decision is taken in favor of the claimant, however, this position is clearly challenged by most scholars. ${ }^{31}$ Justifying their opinion, the latter fairly point out that the course of the process, the behavior of the parties in court and the instructions of the court during the oral hearing of the case may lead to new petitions on the evidence

F Netzer, 'EuBagatellVO' in Hk-ZV (CH Beck, 2016) Art 5, Rn 2; Brokamp (n 7$) 3$.

See, for example, Hau (n 6) Art 5 Rn 2; Hess (n 13) para 10 Rn 93.

28 N Thum, Der Antrag auf mündliche Verhandlung im Verfahren nach billigem Ermessen (NJW 2014) 3198.

29 Toussaint (n 19) para 495a Rn. 17.

30 M Zwickel, Bürgernahe Ziviljustiz: Die französische juridiction de proximité aus deutscher Sicht: zugleich ein Beitrag zur Definition eines Gesamtmodells bürgernaher Justiz (Mohr Siebeck 2010) 79.

Deppenkemper (n 11) para 495a, Rn 17. 
base and other direction of the process, which cannot be known in advance. Thus, even with conditional prospect of approving a decision in favor of the claimant, the case should still be considered with the notification (summons) of the parties.

The basic principle of small claims consideration by the courts of Ukraine is provided in Part 5 of Article 279 of the CPC of Ukraine. ${ }^{32}$ According to this rule, a court may hold an oral hearing with the notification (summons) of the parties at the request of one of the parties or on its own initiative. In the event that there is no such request, the court shall consider the case under simplified procedure without notification of the parties on the materials available in the case. At the same time, the court's consideration of the case (with the summons) of the parties in the presence of the corresponding request is not an obligation, but a right of the Ukrainian court. According to Part 6 of Article 279 of the CPC of Ukraine, a court has the right to refuse the request for an oral hearing of one of the parties in simultaneous presence of certain conditions. First of all, if the subject of the claim is the collection of a monetary amount that does not exceed the abovementioned 5772 Euros. In addition, if the nature of the controversial legal relationship and the subject of proof in the case do not require holding of a court session with the notification of the parties for full and complete establishment of the circumstances of the case.

\section{REPRESENTATION OF THE PARTIES DURING SMALL CASE CONSIDERATION}

The representation of the parties during small case consideration is subject to the regulation of Article 10 of the Regulation (EC) No 861/2007. This article contains a clear indication that representation by a lawyer or other attorney is not mandatory.

The German procedural law contains rules of general action, which oblige parties to represent their interests in court by lawyers. The relevant provisions are enshrined in Paras 78-78 of the CPC of Germany. At the same time, such 'compulsory participation of a lawyer' (Anwaltszwang) does not apply to certain categories of cases, including small claims. ${ }^{33}$

The issue of representation of the parties in Ukraine is decided in a way similar to the German one. Since 2016, the process of introduction of the so-called 'lawyer's monopoly' has begun in Ukraine. ${ }^{34}$ As of November 2018, Ukraine's lawyers have the exclusive right to represent the interests of legal entities and persons in courts of appeal and cassation. Since 1 January 2019, the monopoly

32 For principles of civil proceeding, see more detailed analysis by I Izarova, 'Simplified Action Proceeding: a Novel of Ukrainian Legislation' in I Shutak (ed) Problems of Legislative Regulation of the Development and Adoption of Statutor Instruments (reports of III International Scientific and Practical Conference, Kyiv 2-3 November 2017, Pravo 2017) 214.

33 F Pukall in I Saenger (ed), Hk-ZPO (Nomos 2017), para 495a Rn 5.

34 See, for example, K Livinska, 'Monopolization of Advocacy: Problematic Issues' (2015) No3 Bulletin of Kyiv University of Law 398; S Bychkova, H Churpita,'Issues of a Lawyer Participation in Civil Process of Ukraine' (2014) No9 Bulletin of the Ministry of Justice of Ukraine 116. 
of lawyers for representation will be introduced also in courts of first instance. The legislator has set exceptions from this rule, small claims being one of them. In particular, according to Part 2 of Article 60 of the CPC of Ukraine, during the consideration of small claims (insignificant cases), not only a lawyer may be a representative, but also any other person who has attained eighteen years of age and has civil procedural capacity, except for persons defined in Article 61 of the CPC of Ukraine. Taking into account the abovementioned provisions, one should only welcome the conclusions of the court practice that the allegation of obligatory participation in the case of a lawyer as a plaintiff's representative (provided that the relevant matter belongs to small claims) is erroneous. ${ }^{35}$

\section{EVIDENCE AND PROOVING WHEN CONSIDERING SMALL CLAIMS}

The Regulation (EC) No 861/2007, as well as German and Ukrainian law regulate in detail the issue of evidence and prooving during small claims consideration.

According to the European legislator, one of the prerequisites for the simplicity, speed and proportionality of considering small claims is, among others, the use of modern communications technology by courts. ${ }^{36}$ In this regard, it is logical to set out the obligation of the Member States to promote the use of appropriate technologies by national courts in the Regulation. The wording of Article 8 of the Regulation also indicates the encouragement of more active use of modern technologies by courts in the consideration of small claims. In the previous version of this article (in effect until 13 July 2017), the legislator used the wording the court may ... if available.... ${ }^{37}$ Instead, in the new edition of Part 1 of this article (in effect since 14 July 2017), the preferability of using such technologies by using the wording 'the court shall use...' is emphasized. ${ }^{38}$

The Regulation has not provided for an exhaustive list of communication technologies. This is evidenced, for example, by the use in Part 1 of Article 8 of the Regulations of the wording 'such as. Thus, the legislator provided the addressees of the rule with a peculiar 'field for maneuver' in order to improve the procedure for small claims consideration. As a result, the current version of Article 8 allows courts, if necessary, to change obsolete communication technologies to more modern ones. Today, the legislator defines video and teleconferences (part 1 of Article 8 of the Regulations) as standard ones. ${ }^{39}$ These two types of conferences should also be used if it is necessary to hear persons during the examination of evidence by the court during the written procedure (part 3 of Article 9 of the Regulations).

The basic principle of taking evidence is the principle of the simplest and least burdensome method of taking evidence. Thus, Part 1 of Article 9 of the Regulations

\footnotetext{
35 Decree of the Supreme Court of Ukraine of 30 January 2019 (о ЄДРСР 79684602).

36 Para 20 of the Proposals for a Regulation (EC) № 861/2007.

37 Varga (n 24) Art 8 Rn 1.

38 Hau (n 6) Art 8 Rn 2.

39 Hau (n 6) Art 8 Rn 3.
} 
opens the possibility for courts to consider small claims under the so-called procedure of free proof. ${ }^{40}$ Due to this procedure the court is authorized to organize the examination of evidence on its sole discretion regardless of the consent of the parties to the case.$^{41}$ In particular, the court may carry out the investigation of evidence on the basis of written explanations of witnesses or experts, as well as by written hearing of the parties (part 2 of Article 9 of the Regulations).

By including Para 495 in the national CPC, the German legislator also sought to simplify the court's procedures relating to evidence and prooving. ${ }^{42}$ However, this goal was achieved without restricting the parties in the ways and means of reporting their legal position to the court, for example, by presenting testimony of witnesses to the court. To this end, the German legislator exempted the national court from being bound to mandatory procedures in the field of evidence and prooving. However, the measures have been taken to comply with the basic principles of procedural law. ${ }^{43}$ For this, it granted the national court the power to receive the testimony of witnesses not only in writing, but also in telephone mode. Moreover, in small claims consideration, the German court has received the right to consider not only information from witnesses but also other potentially important carriers of information, in particular, experts.

In the Ukrainian law, the national legislator differentiated the consideration of small claims with the notification (summons) of the parties to the case and without such a summon (Part 8 Article 279 of the CPC of Ukraine). In the event when the court considers a small claim without notice (summons) of the participants to the case, it examines only the evidence and written explanations set forth in the statements on the merits of the case. If the court is considering a case with a notification (summons) of the parties to the case, then it will also hear their oral explanations and testimony.

\section{APPEAL AGAINST COURT DECISIONS IN SMALL CLAIMS}

The issue of challenging court decisions in small claims is regulated differently in the Regulation (EC) No 861/2007, in German and in Ukrainian law.

The Regulation (EC) No 861/2007 contains Article 17, the subject of regulation of which, in accordance with the title of the article, is the issue of 'Appeal. This heading is rather deceptive, since this article does not regulate the procedure for appealing judicial decisions taken as a result of small claims consideration. The subject of its regulation (in particular, Part 1) is only the informational obligation of the Member States. The essence of this obligation is the need for the Member States to inform the Commission whether lex fori regulates the judicial appeal as a result of small claims consideration. Part 2 of Article 17 of the Regulation is also referencing. In the event when national law allows the appeal of court decisions in

$40 \quad$ Kropholler, Hein (n 23) Art 19, Rn 1.

41 Varga (n 24) Art 9 Rn 1; Hess (n 13) para 10 Rn 97; Brokamp (n 7$) 3$.

42 BT-Drucksache 11/4155, s 10.

43 C Paulus, Zivilprozessrecht. Erkenntnisverfahren, Zwangsvollstreckung und Europäisches Zivilprozessrecht (4 Aufl, Springer 2009) Rn 498. 
small claims, the issues of court fees (Article 15a) and funds (Article 16) pursuant to Part II of Article 17 of the Regulations are regulated by the autonomous rules of the Regulations. ${ }^{44}$ Thus, Article 17 of the Regulation does not establish restrictions or obligations for the Member States to regulate the issue of contesting court decisions in small claims at national level. ${ }^{45}$ Its provisions perform primarily a referencing function. The European legislator was forced to refrain from attempts to settle the appeal procedure at the level of the the Regulations, as the lex fori of the Member States had significant differences with regard to this issue. ${ }^{46}$

In the German procedural law, the appeal procedure is regulated in Articles 511541 of the national CPC. The general preconditions for appealing the decisions of the court of first instance - without a special provision for small claims - are established in Part 2 of Article 511 of the CPC of Germany. According to this rule, a decision of a court of first instance may be appealed in an appellate order, if the value of the appeal is more than 600 Euros, or if the court of first instance has admitted such an appeal in its decision. Thus, the first precondition may be the basis for appealing against decisions of the court in small claims only if the value of the appeal is more than 600 Euros ${ }^{47}$ In addition, an appeal to a court of first instance in a small claim is possible if the court of first instance has admitted such an appeal in its decision. The procedural law clearly regulates the cases in which such admission is possible. According to Part 4 of Article 511 of the CPC of Germany, the court of first instance admits an appeal against the decision, if the value of the appeal does not exceed 600 Euros and the case is of fundamental importance, or the need to make a decision on the case by an appellate court is conditioned by the formation of the law or ensuring the unity of judicial practice. If there is no such admission from the court of first instance and the party cannot appeal this decision in an appellate order, it has the right to appeal to the court of first instance with a complaint of violation of their right to a trial under Para 321 of the German CPC. After (mostly unsuccessful) ${ }^{48}$ consideration of this complaint, the party has the opportunity to appeal to the Constitutional Court with a constitutional appeal against the decision of the court of first instance and violation of their right to trial of the said small claim. ${ }^{49}$

The Ukrainian law allows for an appealof a court decision in a small claim (Part 1 of Article 369 of the CPC of Ukraine). The peculiarity of such an appeal under Ukrainian law is that the court of appellate instance is authorized to consider the indicated appeals without notice to the participants of the case. And it is only on its own initiative that the court of appeal may consider such a case in a court session with the notification (summons) of the participants of the case, if the specific circumstances of the case (Part 3 of Article 369 of the CPC of Ukraine) indicate in favor of such a notice (summons).

\footnotetext{
$44 \quad$ Hau (n 6) Art 17 Rn 1.

45 Netzer (n 26) Art 17, Rn 1.

46 Varga (n 24) Art 17, Rn 1.

47 Adolphsen (n 5) para $10 \mathrm{Rn} 41$.

48 Deppenkemper (n 11) para 495a Rn 50.

49 Musielak, Voit, Wittschier (n 25) para 495a Rn 11.
} 


\section{CASSATION APPEAL AGAINST COURT DECISIONS IN SMALL CLAIMS}

The Civil Procedural Code of Ukraine contains a clear provision regarding the possibility of cassation appeal in small claims. According to Para 2 of Part 3 of Article 389 of the CPC of Ukraine, court decisions in small claims are 'filtered'50 and generally not subject to appeal. Exceptions to this rule are permitted only when the cassation appeal concerns a right which is fundamental to the formation of a single law enforcement practice. In addition, a cassation appeal in a small claim is possible if the person submitting the cassation appeal, in accordance with the CPC of Ukraine, is denied the opportunity to refute the circumstances established by the contested court decision in the consideration of another case. Also, a cassation appeal is possible if such a small claim is of significant public interest or is of exceptional importance to the party which filed the cassation appeal. And finally, a court decision on a small claim can be appealed against in cassation order if the court of first instance has classified the claim as small by mistake. The analysis of the court practice of the Supreme Court of Ukraine shows that a significant number of its decisions on cassation complaints in small claims contain general refusals and refusals to open cassation proceedings without detailed justification. ${ }^{51}$ The reason for such refusals by the court is only the absence of circumstances, in the presence of which a court decision in a small claim is subject to appeal.

Unlike the CPC of Ukraine, the German procedural law does not contain any special rules on the possibility of cassation appeal of court decisions in small claims. It only establishes the procedure and prerequisites for a cassation appeal in general. According to Part 1 of Article 542 of the German CPC, final decisions of the appellate instance are subject to cassation appeal. ${ }^{52}$ The procedure for cassation appeal is settled by the German legislator in Part 1 of Article 543 of the National CPC. According to this article, the decision of the Court of Appeal may be appealed against in cassation if the appeal was admitted by the court of appeal in its decision, or such admission was made by the cassation court as a the result of the consideration of the application for the decision of the court of appeals against admitting the cassation appeal. The German CPC binds the court in Part 2 of Article 543 to admit the decision of the appellate instance to a cassation appeal if the relevant case (as in Ukrainian law) passes the relevant 'filters' ${ }^{53}$, in particular, it is of fundamental importance or the need to make a decision on the case by a court of cassation is conditioned by the formation of the law or ensuring the unity of judicial practice.

50 B Hulko, 'Small Claims in the Supreme Court Practice' (2018) No 12-14 (431-433) Judicial and Legal Newspaper 11.

51 See, for example, the Decree of the Supreme Court of Ukraine of 7 Februaty 2019 (case number 79671263), the Decree of the Supreme Court of Ukraine of 7 Februaty 2019 (case number 79684789), the Decree of the Supreme Court of Ukraine of 6 February 2019 (case number 79684729), the Decree of the Supreme Court of Ukraine of 5 February 2019 (case number 79616443).

52 Krüger in MüKoZPO (5 Aufl, CH Beck 2016) ZPO para 542 Rn. 1.

53 S Kessal-Wulf in V Vorwerk, C Wolf (eds), BeckOK ZPO (30 Ed, 15.9.2018) ZPO para 543 Rn 14. 


\section{CONCLUDING REMARKS}

The consolidation of the institute of small claims in the EU law, as well as in the national law of Germany as a member state of the EU, testifies to the urgency and relevance of this institute. Therefore, this novel of the Ukrainian legislator in the national civil process undoubtedly deserves approval and support.

The rules for regulating the qualification of claims as small and their consideration aim at achieving several goals. First of all, the legislator seeks to give potential participants of the case an effective mechanism for judicial protection of their rights and interests. This goal can be achieved by making it easier for participants to access justice by simplifying and speeding up a case consideration following the principle of proportionality.

In addition, these rules are intended to deccrease the load on the judicial system, making it easier for courts to consider such cases. Between these two goals, there must be a balance, since imbalances in favor of the parties or the court will threaten either the first or the second of the stated objectives. Thus, the legislator should provide in the procedural law the levers which will serve as a guarantee and assurance of this balance. And even if one of these or other levers do not work at the stage of consideration of the case by the court of first instance, the appeal and/ or cassation instance should resolve this situation.

The findings of this study should be divided into two groups. The first group of conclusions will deal with the formal aspects of appealing to the court within the framework of the small claims institute. The second group of conclusions will touch upon the content of the legal regulation of the small claims institute.

The position of the procedural law of Ukraine, according to which representation of the interests of the parties by lawyers during the small claims consideration is not obligatory, should be assessed positively. The introduction of a lawyer's monopoly in Ukraine in this category of cases would be a significant burden on individual parties of the trial. In Germany, the participants of a process in other categories of cases have the opportunity to take advantage of effective mechanisms of state or non-state (in particular, insurance) support in paying lawyers' fees. In Ukraine, some of these mechanisms are rather ineffective, while others are almost absent.

However, by releasing potential plaintiffs from the duty to use lawyers' services, the Ukrainian legislator only made a half-step towards ensuring access of such plaintiffs to justice. The prerequisite for such access is, among other things, the preparation and filing of a suit. And it is at this stage that the average plaintiff may have difficulties. They will be substantially reduced by the standardized forms for claims to the court. This tool is not new, it has been tested by a European legislator and its efficiency is proven. The consolidation of such forms at the legislative level in Ukraine will facilitate access to justice of future plaintiffs, which would not be an overwhelming burden on justice itself. In this way, not only the principles of simplicity and speed, but also proportionality will be adhered to.

The comparative analysis of Part 6 of Article 19 of the CPC of Ukraine and Para 495 of the CPC of Germany testifies that today the Ukrainian procedural law establishes considerably wider, in comparison with the German procedural law, 
limits for assigning the relevant claim to a category of small claims. In addition, taking into account the powers of the Ukrainian court to consider as the small claims cases of insignificant complexity, which claim value exceeds approximately EUR $31,405^{54}$, the differences within small claims legislation according to the Ukrainian and German law become apparent. And only in comparison with the norms of the EU law, in particular, Part 1 of Article 2 of the Regulation (EC) No $861 / 2007$ concerning the aspect of threshold of small claims, these differences lose their essential character.

Both Ukrainian and German procedural law resolved the legal consequences of changing the value of a claim in small claim procedure. In general, these legal consequences are comparable, in particular, in the part where such a case is subject to review under the general procedure.

The essential difference between the CPC of Ukraine and the CPC of Germany lies within the regulation of the powers of the court to decide whether the small claim is to be considered with the notification (summons) of the parties or without it. While the German court should consider a small claim with the notification (summons) of the parties in the presence of the corresponding request, the Ukrainian court has the right (even if there is a corresponding request) to decline it. Although the CPC of Ukraine theoretically sets a high barrier for a court that would prevent its potentially arbitrary rejection of the relevant request, it would be impossible to exclude a possibility of a formal reference by the court to the lack of a need for a court hearing, given the nature of the controversial legal relationship and the subject of evidence. Thus, Part 6 of Article 289 of the CPC creates the prerequisites for simplifying the consideration of small claims by the court by confining the participants of the case in their participation in the case. Its provisions, being tendentiously similar to Part 1, Article 5 of the Regulation, contribute to a potential imbalance between the interests of the court and the parties of the case in Ukraine. Practice will show how the Ukrainian courts of first instance will use this tool and how the higher courts will react. However, the abuse of such a liberal wording of Part 6, Article 279 of the $\mathrm{CPC}$ will create a risk for the participants of the case and may become one of the prerequisites for their further appeal to the ECHR. And even if Western European scholars warn against possible cases of judicial arbitrariness caused by the wording of Part 1, Article 5 of the Regulations ${ }^{55}$, then what can you expect from similar legislation in the Eastern European states, in particular, in Ukraine, whose judicial system is just beginning to take shape?

Significant differences not in favor of the Ukrainian model of small claims consideration are also observed regarding issues of evidence and prooving. If the Ukrainian court considers a small claim without notifying (summons) the participants of the case, then it will not hear their verbal explanations or testimony. However, it is the testimonies of participants and witnesses that may have a critical significance for the participants themselves. The Ukrainian legislator does not list

54 See n 21-22 in Section 3 of the article for the established by the Ukrainian legislator threshold for the value of a claim for qualifying of a claim as a small one.

55 Varga (n 24) Art 5 Rn 2. 
the ability to take evidence in telephone mode for court's consideration, not to mention the experts' conclusions.

Critically important differences in the Ukrainian and German procedural laws lie in such an important procedural instrument as appealing against the decision of the court of first instance. And although the procedural laws of both states allow such an appeal, the disproportion not in favour of the parties is concealed in the Ukrainian law. Theoretically, the Ukrainian court of appellate instance may consider such a case in a court session with the notification (summons) of the participants in the case. However, would the courts of appeal that place their interest in discharging from the influx of cases above the interests of the parties to bring their legal position to court, taking directly the participation in the court session, pay attention to this rule? At the stage of formation and reform of the judicial system in Ukraine, it is impossible to exclude the danger of ignoring this rule completely. Thus, Part 3 of Article 369 of the CPC of Ukraine contains serious risks for balancing the interests of the court and the parties. The more perfect wording also requires prerequisites for a cassation appeal of decisions of the Ukrainian court in small claims.

Summarizing the above, it should be noted that the Ukrainian legislator made the first steps towards the small claims consideration in the national process. However, this should not be a final stop. Given the social significance of the category of small claims, the regulation of this institute should be actively and urgently improved, including in the light of European experience. Time will tell how fast a Ukrainian legislator can make progress in this matter. 